\title{
Editorial \\ Philosophy of Education: The Promise of Education and Grief
}

\author{
Anne B. Reinertsen (1)
}

check for

updates

Citation: Reinertsen, A.B. Philosophy

of Education: The Promise of

Education and Grief. Educ. Sci. 2022,

12, 32. https://doi.org/10.3390/

educsci12010032

Received: 30 December 2021

Accepted: 4 January 2022

Published: 7 January 2022

Publisher's Note: MDPI stays neutral with regard to jurisdictional claims in published maps and institutional affiliations.

Copyright: (C) 2022 by the author. Licensee MDPI, Basel, Switzerland. This article is an open access article distributed under the terms and conditions of the Creative Commons Attribution (CC BY) license (https:// creativecommons.org/licenses/by/ $4.0 /)$.
Department of Teacher Education, Østfold University College, BRA veien 4, 1757 Halden, Norway; annebre@hiof.no

\section{Introduction}

This is a collection of articles preoccupied with the future of education. The approaches are all different, but what they have in common is a wish to explore and contribute to educational innovations moving beyond traditions or norms that project old common sense into the lives and education of young people and children. Through questioning assumed hierarchies of knowledge and language, the authors create openings towards expanded meaning fields, nourishing a valuable diversity of onto-epistemic cultures, inclusiveness and empowerment of learners. The concept of grief in this Special Issue is simultaneously a consequence of wordless loss and potentiality.

\section{The Articles}

The first article, entitled Lost and Found-Unfolding and Refolding Aesthetic Learning Processes, was written by Annika Hellman and Ulla Lind. Their theme is the ongoing marketisation of education being a great loss for visual arts education because explorative learning processes are marginalized in favor of more goal-oriented learning. Working within a Deleuze and Guattarian [1] philosophical framework, Hellman and Lind examine the folding, unfolding, and refolding of aesthetic learning processes, suggesting productive concepts and practices ultimately preparing students for an uncertain future.

The second article was written by Anne B. Reinertsen and is titled Oxymoron Education: A Poem about Actualizing Affect for Public Good. It revolves around the constitution of subjectivity and the child being our primary measurement indicator for educational quality. The project is risky and one of loss, as any negotiation for Others might be. The method, however, is simple: through using the concept of oxymorons as a rhetorical and epigrammatic device for revealing paradoxes - and through this taking, part in polysemantic ambiguityother ways of using language are explored and new concepts are possibilized and created. Through a montage of thoughts, theories and stories that converge and diverge, hopefully, the pedagogical thinking and exploring is given a constant continuation. Reinertsen argues for another rationale for education and fugitive planning, another conceptualization of the power, position and function of language in and for learning, meaning making and change.

The third article was written by Bente Ulla and Ann-Sofi Larsen. Their theme is Humble Hops in Mentorship and education: Thinking with Temporality. The article juxtaposes mentoring with an extended concept of time, arguing against the idea of mentoring as a unilaterally forward-moving progression. Through using an inherited object from the past as an example, Ulla and Larsen discuss how time and temporality unfold in mentoring in the teaching profession and explore how temporality might create different potentialities of hope.

Anna Lydia Svalastog, Shawn Wilson and Ketil Lenert Hansen have written the article entitled Knowledge versus Education in the Margins: An Indigenous and Feminist Critique of Education. This article highlights the perceptions and expectations of knowledge that many people, including educators and policymakers, take for granted. The focus is Indigenous studies and gender studies, showing how modern education undermines these fields of studies. The authors have chosen narratives of exposure to knowledge outside the 
educational system, as well as narratives of limitations posed upon us by the educational system to investigate and discuss grief on areas of knowledge that society cries for, but the educational system continuously finds ways to resist. The message is that the educational system needs to re-evaluate its strategies to stay relevant.

Chamila H. Dasanayaka, Chamil Abeykoon, R. A. A. S. Ranaweera and Isuru Koswatte have authored The Impact of the Performance Appraisal Process on Job Satisfaction of the Academic Staff in Higher Educational Institutions. The article is an examination of the effects of the Performance Appraisal Process on job satisfaction of the university academic staff. The authors realized that the majority of the academic staff of the source university were dissatisfied with the current performance appraisal process. Further research in this area is highly recommended to explore extensive information to create a favorable work/study environment for both staff and students within universities and HE institutions.

The sixth article is about Encounters in and with Summer Camps-Happy Childhood, Alternative Bildung, or What? It was written by Iuliia Afonkina, Werner Bigell, Valerii Chernik, Torun Granstrøm Ekeland, Tatiana Kuzmicheva, Kirsten Elisabeth Stien and Herbert Zoglowek. Although they are commonly associated with recreation, the authors argue that summer camps for children can be seen as educational arenas that both supplement and challenge school education, providing education in a broad sense of bildung. The main focus is on summer camps in Russia, and the findings indicate that learning tends to be non-instrumental, allowing room for play and experimentation for both pupils and teachers.

The seventh article is titled Pedagogy of Happiness: A Russian View, and was authored by Valerii Chernik, Iulija Afonkina and Tatiana Kuzmicheva, who discuss the topic of happiness. The authors claim that, until now, there has been no unity in understanding the essence, sources, and components of happiness across various sciences. Often, the interpretation of the phenomenon of happiness is limited to the analysis of the works of philosophers of antiquity, the European Middle Ages, modern and recent history, and many researchers are in a kind of Eurocentric captivity. Consciously or accidentally, however, the works of Russian thinkers are often not considered, which hinders the creation of a holistic and more objective picture of such an important aspect of every person's life. In order to overcome this Eurocentric bias, this study suggests tracing back the main stages of the development of the idea of happiness in Russia from the era of Peter the Great to the present.

The eighth article was written by Bosse Bergstedt. The title is The Ontology of Becoming: To Research and Become with the World, and it aims is to explore a perspective of the ontology of becoming, which makes it possible to study the emergence of phenomena and thereby broaden the understanding of how knowledge is created. The article describes both philosophical points of departure and methodology and research practice. After an introduction describing the basic ontological stating points, the article continues to describe how a research apparatus can be constructed and used to carry out analyses based on the ontology of becoming: a research apparatus where the body's senses and mobility are given a prominent role through a haptic sensorium. Last but not least, the article describes examples of phenomena that can be explored with an onto-analysis of becoming. Special focus is placed on the border phenomenon of sound.

Andrew John Thomas has written the article The Justice of Theory: How and What Do Educational Skills Distribute? Thomas asks whether educational theories affect enfranchisement asymmetrically, and he analyzes two sets of thinking skills in religious education as apparatuses, taking observations and political documents as a starting point. The thinking skills are described in terms of the roles they allocate, the attention and effects they direct, values and truth-criteria they foster, and the extent to which they make aspects of religion visible and invisible. Taking a cue from Butler's [2] question, "When is Life Grievable?", attention is paid more to the distribution of an apparatus than its validity or effectiveness. How do sets of thinking skills distribute opportunities to make particular strategic choices? When is learning truly and equally shared? 
The last article is this Special Issue on The Promise of Education and Grief was written by Carla C. Ramirez. The title is Epistemic Disobedience and Grief in Academia. Drawing on conversations with foreign women in academic positions at one major University in Norway, the article is inspired by Barad's [3] and Haraway's [4] theorizations on how matter and discourse are mutually constituted through a diffractive approach. Understanding diffraction as an embodied engagement, a becoming with the data through shared entanglements, the article argues that the researcher's personal background cannot be separated from the data produced. Through immersion in assemblages of contradictions, strength, and resistance, this article contends that policymakers' good intentions of diversity in higher education, and the existence of different bodies, are shaking the world of academia, albeit slowly.

\section{Educational Innovations and Difference}

I hope this collection of articles shows why and how it is possible and important to think philosophy in general, educational philosophy specifically, science, art and literature, not as separate territories established through relations of oppositions, but as a common concern possibilizing and producing fruitful research questions. For example: How to consider the particularity of the one together with those of others?; How can we judge the value of what other researchers/people create without denying own affiliations?; How can plurivers and disagreements be added as a positive function, and contribute to consolidating community? This is ultimately a defense and fight for educational policies and educators who can appreciate potential based in difference, one that will not uncritically harmonize to include, but one who realizes that it is the cracks in our philosophical and pedagogical constructions, systems and programs themselves that possibilize the human and the transgressive both. Indirectly, it is also a call for us all to pay attention to and resist unintentional productions of exclusion, and all colonizing processes that include superior knowledge.

Funding: This research received no external funding.

Conflicts of Interest: The author declare no conflict of interest.

\section{References}

1. Deleuze, G.; Guattari, F. What Is Philosophy? Verso: London, UK, 1994.

2. Butler, J. Frames of War: When Is Life Grievable? Verso: London, UK, 2010.

3. Barad, K. Meeting the Universe Halfway: Quantum Physics and the Entanglement of Matter and Meaning; Duke University Press: London, UK, 2007.

4. Haraway, D. The Haraway Reader; Routledge: London, UK, 2004. 